\title{
Analysis of the Impact of the Presence of PT. Martabe Gold Mine Batangtoru on the Level of Welfare of the Community Batangtoru South Tapanuli Regency
}

\author{
Khairul Ali Hutasuhut ${ }^{1}$, HB. Tarmizi SU ${ }^{2}$, Rujiman ${ }^{3}$ \\ ${ }^{1}$ Posgraduate Students Faculty of Economics and Business, Department of Economics, Universitas Sumatera \\ Utara, Indonesia \\ ${ }^{2,3}$ Postgraduate Lecturer Faculty of Economics and Business, Department of Economics, Universitas Sumatera \\ Utara, Indonesia
}

Corresponding Author: Khairul Ali Hutasuhut

\begin{abstract}
This research was conducted to determine the impact of the existence of PT. Martabe Batang Toru Gold Mine on the level of community welfare in Batang Toru District, South Tapanuli Regency, by comparing the situation before and after the existence of the mine in the 2011-2021 period. The population in this study is the community of Batang Toru District which consists of 11 villages, with a population of 17,379 people. The sample in this study amounted to 100 people who were determined using the Slovin formula with a $90 \%$ confidence level. The types of data used in this study are primary and secondary data. The analysis in this study uses the mean difference test and partial $t$ test using SPSS 23. The results in this study indicate that the existence of mining has a positive impact on the welfare of the people of Batang Toru District.
\end{abstract}

Keywords: PT. Martabe Batangtoru Gold Mine, Average Difference Test, $t$ Test, Community Welfare.

\section{INTRODUCTION}

Indonesia is one Country which has natural resources is very abundant. Natural resources (both renewable and nonrenewable) are a resource that is essential for human survival. Loss or reduced availability of these resources will have a major impact for the survival of mankind in the face of the earth (Fauzi, 2004). The richness of this nature anyway, which makes Indonesia was colonized for centuries by the Dutch and Japanese.

One of natural resources in Indonesia is a mineral of gold and silver, which are included in the class of resources that cannot be renewed. The mining sector is one of the mainstays for earning foreign exchange in the framework of the continuity of the development of the country.

Indonesia is an archipelago, consisting of 34 provinces are bestowed with abundant natural resources, one of which is the province of North Sumatra. North Sumatra province is an agricultural area which became the center of the development of plantation and horticulture on the one hand, is one of the centers of development of the industry and the gate of tourism in Indonesia through the strait of Malacca. In addition, one of the sectors that support economic growth comes from the mining sector.

Mining is basically a process of transfer of natural resources into capital to the real economy for the Country and subsequently becoming capital social. Capital that is generated is expected to increase the value of the quality of the members of the nation to face the day ahead of him independently. In the process of 
transfer of the need to pay attention to the interaction between the factors of social, economic, and environmental impacts that occur are known as early as possible (Soelistijo 2005).

The mining business is part or all of the stages of the activities in the framework of the research, management and exploitation of coal and minerals that include general investigation, exploration, feasibility studies, construction, mining, processing and refining, transportation and sales as well as post-mine activities (Article 1, point 6 of Act No.4 year 2009 on Has the Minerals and Coal).

Based on a Survey in 2006 noted that there are 27 types of mining non-metal (group C), 15 types of goods of metal mine and six kinds of oil, gas (oil and gas) and energy. Mines non-metal, among others, limestone, dolomite, quartz sand, sulfur, kaolin, siliceous fossil, and bentonite. While the mines metals include gold, silver, copper, and lead. While potential oil and gas and energy, among others, petroleum, natural gas and geothermal. When this has been done the exploitation of petroleum in North Sumatra, with production in 2006 21,000 barrels of petroleum.

Mining is a sector that is very promising and has a potential value that high, especially in improving the economy of the area around the mining area. Coal, petroleum, gold and silver is a mineral that many find in Indonesia. The material of the mine belongs to the category of which can not be renewed.

The impact of mining activities according to Muhammad (2000) can be positive for the local mining magnate. While Noor (2000) said that the mining activities are negative for the ecosystem of the local area. The emergence of a negative and positive impact of the mining business occurs in stages, exploration, exploitation including the transport and sale of mining and post-mining.

The direct contribution of mining companies to kesejahtaan local people covered in the community empowerment program that is being developed by each of the mining companies. The Program is, is a social investment that will indirectly improve the performance of the production company, for investment social can be eliminate or reduce the conflict between the company and the community around the mine company.

In addition to community empowerment program mining entrepreneurs also have to develop a corporate social responsibility. The essence of corporate social responsibility are the mining companies have a moral obligation to help the livelihoods of social, economic, community sekititar the search for profit. The consequences of corporate social responsibility, namely the mining entrepreneurs must provide both greater social or cost that is aimed for the benefit and welfare of the public.

Table 1:The rate of growth of PDRB of South Tapanuli Regency on the Basis of Constant Prices of 2010 according to the Field Business/Sector (Percent)

\begin{tabular}{|l|l|l|l|}
\hline No & Category/ Business Field & 2018 & 2019 \\
\hline 1. & Agriculture, Forestry, and Fisheries & 5,28 & 4,09 \\
\hline 2. & Mining and Quarrying & $-0,70$ & 2,97 \\
\hline 3. & Processing Industry & 4,88 & 5,58 \\
\hline 4. & Procurement of Electricity and Gas & 6,78 & 6,81 \\
\hline 5. & $\begin{array}{l}\text { Water supply, Waste Management, } \\
\text { Waste and Recycling }\end{array}$ & 5,55 & 7,52 \\
\hline 6. & Construction & 8,64 & 8,62 \\
\hline 7. & $\begin{array}{l}\text { Wholesale and Retail trade; Repair of } \\
\text { Cars and Motorcycles }\end{array}$ & 6,70 & 6,76 \\
\hline 8. & Transportation and Warehousing & 6,67 & 6,55 \\
\hline 9. & $\begin{array}{l}\text { The provision of Accommodation and } \\
\text { Eating and Drinking }\end{array}$ & 7,84 & 7,80 \\
\hline 10. & Information and Communication & 8,50 & 8,47 \\
\hline 11. & Financial and Insurance services & 3,14 & 3,27 \\
\hline 12. & Real Estate & 6,60 & 6,83 \\
\hline 13. & The Services Of The Company & 5,40 & 5,82 \\
\hline 14 & $\begin{array}{l}\text { Government administration, Defense } \\
\text { and Compulsory Social security }\end{array}$ & 7,73 & 7,02 \\
\hline 15 & Educational Services & 7,02 & 7,05 \\
\hline 16 & Health services and Social Activities & 7,50 & 7,70 \\
\hline 17 & Other services & 6,54 & 6,09 \\
\hline GROSS REGIONAL DOMESTIC PRODUCT & 5,19 & 5.23 \\
\hline & Source : Statistics South Tapanuli (Data Processed) \\
\hline
\end{tabular}

The implementation of the gold mining in the District of Batang toru started in 1997 with the found gold reserves through the process of sampling sediment in rivers by Normandy Anglo Ltd. Since that time the government gave the contract works to the company PT. Angincourt Resources (PT.AR) to gold mining, and the 
company began to actively perform activities since 2003. Since that time the company performs a variety of exploration activities in the District of Batangtoru.

Data from the above table it can be concluded, the performance of the economy of south Tapanuli in the year 2019 when compared to 2018, which is described by PDRB on the basis of the prices of a base year of 2010 experiencing the acceleration of about 0.4 percent. Increase the acceleration is caused by the increasing growth in some sectors of the economy. Mining and quarrying amounted to 2.27 percent, followed by the processing industry increased by 0.7 percent, the sector's procurement of electricity and gas also increased by 0.3 percent, the sector of water supply, refineries garbage, waste and recycling also increased sebesaar 1.97 percent, the sector of retail trade and large; reprasi car and motorcycle also increased by 0.6 percent, the financial Services sector and insurance increased by 0.13 percent, the sector of real estate services increased by 0.23 percent, the service sector companies increased by 0.42 percent, the sector of educational services increased by 0.3 percent, and health services and the work of the social increased by 0.20 percent.

Table 2: The Source Of The Economic Growth Of South Tapanuli Regency $2019(\%)$

\begin{tabular}{|l|l|l|}
\hline No & The Field Of Business/Sector & $\begin{array}{l}\text { Sources } \\
\text { Growth In } \\
(\boldsymbol{\%})\end{array}$ \\
\hline 1 & Agriculture, Forestry, and Fisheries & 2,05 \\
2 & Mining and Quarrying & 0,78 \\
3 & Construction & 0,63 \\
4 & Wholesale and retail trade ; repair & 0,62 \\
5 & of cars and motorcycles & 0,35 \\
6 & Processing Industry & 0,80 \\
\hline \multicolumn{2}{|c|}{ Field Of Other Business } & 5,23 \\
\hline PDRB & Source : Statistics South Tapanuli (data processed)
\end{tabular}

The growth of the field of business of Agriculture, Fisheries and Forestry are still the source of the creation of the growth of South Tapanuli the largest, followed by the field of Mining and Quarrying. In 2019, the value of the economic growth of South Tapanuli Regency value 5,23 percent, was created by the field of Agriculture, Fisheries and Forestry of 2.05 percent, followed by
Mining and Quarrying amounted to 0.78 percent, Construction by 0.63 percent, wholesale and Retail Trade; Repair of Cars and Motorcycles of 0.62 percent, Industrial Processing by 0.35 percent, and the field of other businesses amounted to 0.80 percent is a combination of all businesses in addition to businesses which have been mentioned.

Table 3: Development of PDRB per Capita of South Tapanuli Regency 2015-2019 (Thousand Dollars)

\begin{tabular}{|c|lr|l|l|}
\hline \multirow{5}{*}{ Year } & $\begin{array}{l}\text { PDRB } \\
\text { Capita Per } \\
\text { Current Prices) } \\
\text { (At } \\
\text { (Rp.000) }\end{array}$ & $\begin{array}{l}\text { PDRB } \\
\text { Capita } \\
\text { (Constant } \\
\text { Prices) } \\
\text { (Rp.000) }\end{array}$ & $\begin{array}{l}\text { Growth PDRB } \\
\text { Per } \\
\text { (Constant } \\
\text { Prices) }(\%)\end{array}$ \\
\hline 2015 & $36,562.82$ & $28,753.43$ & 4,11 \\
2016 & $39,599.86$ & $30,028.96$ & 4,44 \\
2017 & $42,959.51$ & $31,401.97$ & 4,57 \\
2018 & $45,961.32$ & $32,830.96$ & 4,55 \\
2019 & $49,417.64$ & $34,347.61$ & 4,62 \\
\hline
\end{tabular}

PDRB per capita is a picture of the average income that may be received by each resident as a result of the production process. PDRB Per capita is obtained by dividing the total value of the PDRB by the total population mid-year.

The PDRB per capita of South Tapanuli on the basis of prices prevailing in the year 2015 amounted to 36,56 million dollars and increased to 49,42 million dollars in 2019. When viewed according to the prevailing prices, the figures from year to year to show improvement. Meanwhile, if viewed from the calculation on the basis of constant prices of 2010, namely to eliminate the influence of rising prices (inflation), then in the period 2015-2019 increased relatively stable. In 2019, the PDRB per capita of South Tapanuli on the basis of constant prices reached 34.35 million dollars. Based on the basis of constant prices of 2010, growth in PDRB per capita since the year 2015 to the year 2019 has fluctuated. In 2015, PDRB per capita of South Tapanuli Regency grew by 4.11 percent, while the year 2019 grew by $4.62 \%$.

With the Presence of PT. Martabe Gold mine Batangtoru, the authors are interested in examining whether the PT. Martabe Batang Toru gives positive impact 
for the welfare of the community or just the opposite. This is due, before the activities of the mining community Kecamatan Batang Toru most of its income derived from agriculture and plantation sector. But on the other hand the existence of the mine also open field work and also open up the field of business for the community around the mine.

\section{LITERATURE REVIEW}

\section{Labor}

Labor has some definition, according to Law No. 13 Year 2003 concerning manpower, labor is any person who is able to do the work to produce goods and services to meet the needs of themselves or to society

\section{Revenue}

Revenue is the result of work (effort or so). While revenue in the dictionary management is the money received by individuals, companies and other organizations in the form of wages, salaries, rent, interest, commissions, costs and profit.

\section{Poverty}

Poverty is a condition of inability economically to meet the standards of the average life of the community in an area. The condition of this inability is characterized by the low ability of income to meet basic needs for either food, clothing, and board.

\section{Health}

Health is healthy condition of body, soul, and social that allow everyone to live socially and economically productive. According to WHO health is a state of perfect physical, mental and social is not only free from disease or infirmity.

\section{Education}

Education as expressed in the Great Dictionary of the Indonesian Language is defined as the process of changing the attitude and behaviour of a person or group of people in the business of mature man through the efforts of teaching and training. Definition of education put forward by M. J. Langeveld (Revrisond Baswir et al., 2003).

\section{Information Technology}

Information technology is the means and the infrastructure (hardware, software, useware) system and method to acquire, transmit, process, interpret, store, organize, and use data in a meaningful way.

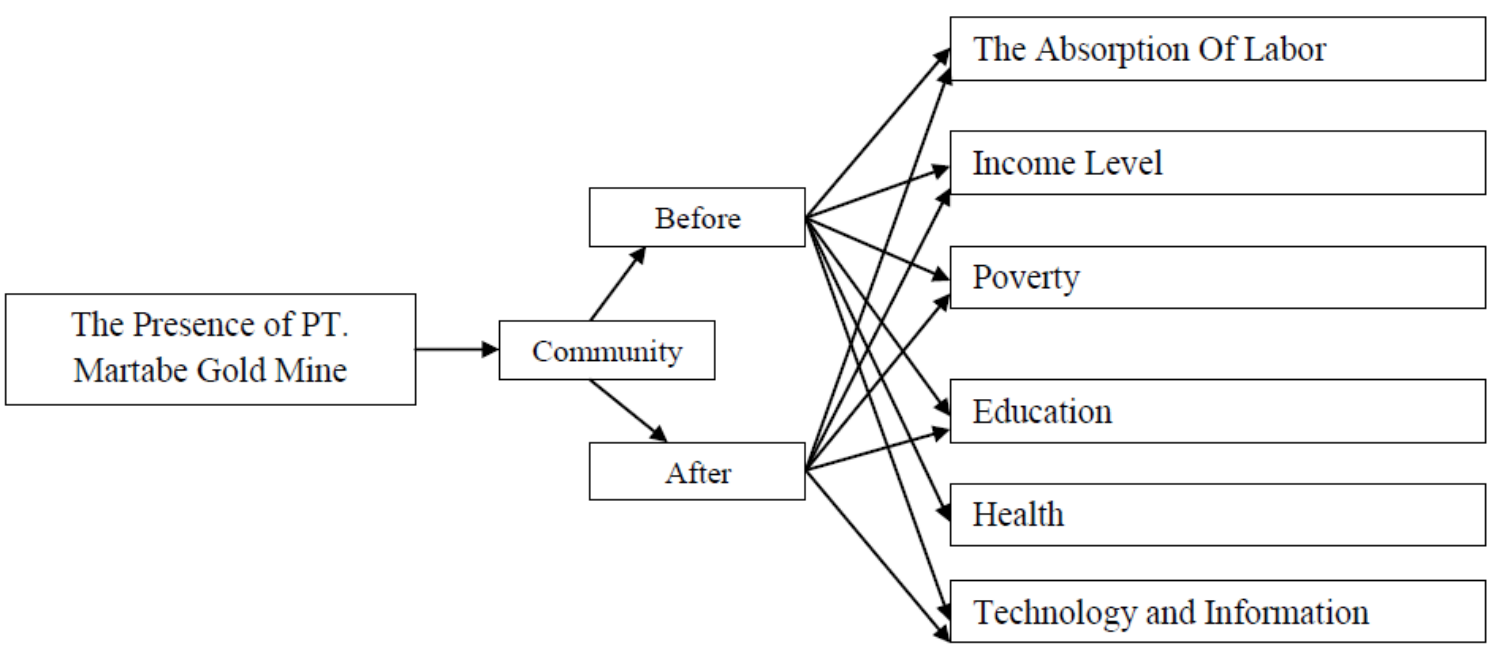

Figure 1. Conceptual Framework

\section{Hypothesis}

Based on the background research and the relationship between variables, then the research hypothesis:
1. The Presence Of PT. Martabe Gold Mine Batangtoru, Have A Positive Impact On Labor Absorption In The 
Community District. Batangtoru South Tapanuli Regency.

2. The Presence Of PT. Martabe Gold Mine Batangtoru, Have A Positive Impact On The Income Of The Community District. Batangtoru South Tapanuli Regency.

3. The Presence Of PT. Martabe Gold Mine Batangtoru, Have A Positive Impact On The Poverty Level Of The Community District. Batangtoru South Tapanuli Regency.

4. The Presence Of PT. Martabe Gold Mine Batangtoru, Have A Positive Impact On Community Education District. Batangtoru South Tapanuli Regency.

5. The Presence Of PT. Martabe Gold Mine Batangtoru, Have A Positive Impact And Influence On Public Health District. Batangtoru South Tapanuli Regency.

6. The Existence Of PT. Gold Mine Matabe Batangtoru, Have A Positive Impact On The Development Of Technology And Information Society Of The District Batangtoru South Tapanuli Regency.

\section{MATERIAL AND METHODS}

The method used to analyze the impact of a project is to compare the situation before and after the project. PT. Martabe Gold mine began producing Gold since 2012. Circumstances Prior to the project are the level of community welfare batangtoru before the presence of PT.Martabe Gold mine Batangtoru yaiu in 2011. On the contrary circumstances After the project is the level of community welfare batangtoru on time after the presence of PT.Martabe Gold mine Batangtoru in 2021. In this study it will compare the state of the welfare of the community batangtoru in 2011 before the presence of mines and in 2021 after the presence of mines and air operations. In this study, the respondents are the people in the District Batangtoru.
The population in this study is the community of the district batangtoru of 23 villages, where there are 11 villages in the scope of mining gold, among others, namely: the Villages, Wek I, Wek II, Wek III, Wek IV, Napa, Telo, Aek Pining, Village of Wells, Huta Godang, Rock a Hula, Village Plantation Batangtoru, and each of the village has a population that is different. The sample is part of population number and characteristics possessed by the population (Sugiyono, 2014). Each village will be selected some of the people who will be the sample, so the number of samples in this study were 99 people. The method of determining the sample using the method of simple random.

The type and Source of Data used is Primary Data. Primary Data is data obtained or collected by the researcher by means of directly from the source. To obtain primary data, researchers are obliged to collect it directly. The way that can be used by researchers to find the primary data are observation, interview or distributing questionnaire. Secondary Data is data obtained from the Central bureau of Statistics, books, literature, internet, journals, and other reading-related research that is used as supporting data.

\section{RESULTS AND DISCUSSION}

Based on the explanation of the respondent, the presence of PT. Martabe Gold mine provides a positive influence on the economic activity of da social community so that the welfare of the community in the District of Batang Toru is increasing.

Donations PT. Martabe Gold mine Batangtoru to the job opportunities and economy that influence the reduction of poverty and increased income communities. Although the employees of the company only $50 \%$ of labor local who worked at PT. Martabe Batang Toru such. This is due to the human resources (HR) for the local community which is still less when compared human resources (HR) is from outside the area. 
PT. Martabe Gold mine also contributes to the social community, namely the increased facilities of education, health and development of IT which is quite significant. In the means of da educational infrastructure such as improving the quality of teachers, provide bbeasiswa for students achievement, provision shops (stationery) for the disciples and others.

In health facilities and infrastructure PT. Martabe Batang Toru also opened a private hospital for the workers and the surrounding community (Common). The gold mine is also often do free immunizations.

PT. Martabe Gold mine Batangtoru also play an important role in the development of IT in the District of Batangtoru, this is caused by the PT. Martabe gold mine batangtoru a lot of cooperation with the company provider to build a network of the internet that is stable in the District of Batang Toru. The gold mine also often give donations in the form of a computer/laptop to the existing schools in the District of Batang Toru.
In addition to infrastructure health education and the development of IT, PT. Martabe Gold mine also contribute help to the community. Such as the construction of places of worship, the provision of nursing homes, fire departments, providing the services of the ambulance, and others.

\section{The Results Of The Different Test Average}

The analysis used in this research is testing the average single (single sample ttest), namely testing the difference in the average of six variables mutually free. The impact of the presence of PT. Martabe Batang Toru on the level of the livelihoods of the people in the District of Batang Toru, Kab. Tapanuli Selatan then that will be analyzed is the variable: employment, incomes, poverty, health facilities and infrastructure, education facilities and infrastructure, the development of technology and information.

The analysis carried out through different test average of livelihoods of communities before and after the PT. Martabe Batang Toru.

\begin{tabular}{l} 
Table 4: The results of the different Test average \\
\begin{tabular}{|l|l|l|l|l|}
\hline & Mean & STD.Error Mean & t-stat & Sig. \\
\hline The absorption of labor & 6.0900 & .14914 & 40.835 & .000 \\
Revenue & 7.2200 & .12109 & 59.625 & .000 \\
Poverty & 6.3700 & .13000 & 49.000 & .000 \\
Health & 6.6800 & .14899 & 44.835 & .000 \\
Education & 6.9900 & .12988 & 53.821 & .000 \\
Technology and Information & 6.8600 & .11011 & 62.299 & .000 \\
\hline
\end{tabular} \\
\hline
\end{tabular}

Based on the different test average on the table above by using the t test obtained t count value of each variable by $40.835,59.625,49.000,44.835,53.821$, and 62.299 with the significance of 0.000 , which means there are significant differences in the variable employment, income, poverty, health, education, and information technology before and after the PT. Martabe Batang Toru. Where there is an increase in each variable on the before and after the presence of PT. Gold Mine Maratabe Batang Toru.

\section{The t test (Partial)}

\begin{tabular}{|c|c|c|c|c|c|c|c|}
\hline \multicolumn{8}{|c|}{ est Value $=0$} \\
\hline & \multirow[t]{2}{*}{$\mathbf{T}$ (count) } & \multirow[t]{2}{*}{ T (table) } & \multirow[t]{2}{*}{ df } & \multirow[t]{2}{*}{ Sig. (2-tailed) } & \multirow[t]{2}{*}{ Mean Difference } & \multicolumn{2}{|c|}{$90 \%$ Confidence Interval of the Difference } \\
\hline & & & & & & Lower & Upper \\
\hline Labor & 40.835 & 2.36 & 94 & .000 & 6.09000 & 5.8424 & 6.3376 \\
\hline Revenue & 59.625 & 2.36 & 94 & .000 & 7.22000 & 7.0189 & 7.4211 \\
\hline Poverty & 49.000 & 2.36 & 94 & .000 & 6.37000 & 6.1541 & 6.5859 \\
\hline Health & 44.835 & 2.36 & 94 & .000 & 6.68000 & 6.4326 & 6.9274 \\
\hline Education & 53.821 & 2.36 & 94 & .000 & 6.99000 & 6.7744 & 7.2056 \\
\hline Technology & 62.299 & 2.36 & 94 & .000 & 6.86000 & 6.6772 & 7.0428 \\
\hline
\end{tabular}


This test is intended to mengetahi how far the influence of a positive and significant presence of PT. Martabe Batang Toru against the livelihoods of the people consisting of 6 (six) variables, namely: employment, income, poverty, health, education, technology and information.

The results of the Test are:

Error rate $(\alpha=10 \%)$ and degrees of freedom $(\mathrm{df})=(\mathrm{n}-\mathrm{k})$

$\mathrm{n}=$ Total sample of 100 respondents

$\mathrm{k}=$ Number of variables used is 6 , then the value of Ttable $10 \%$ (100).

PT. Martabe Batang Toru positive effect of da significantly to the livelihoods of the people. This daapa seen from the value of significance $(0.000<0,1)$ da value of Tcount each variable have been tested, namely 40.835, 59.265, 49.000, 44.835, 53.821, and $62.299>$ Ttable (2.36) which means that the Presence of PT. Martabe Batang Toru positive effect on the level of welfare of the people of the District of Batang Toru, South Tapanuli Regency, (Ha accepted).

\section{CONCLUSIONS AND RECOMMENDATIONS CONCLUSIONS}

Based on the results of this study can be concluded as follows:

1. The presence of PT. Martabe Batang Toru has a positive impact on the absorption of labor society in the District of Batang Toru South Tapanuli Regency.

2. The presence of PT. Martabe Batang Toru positive impact on the income level of the people in the District of Batang Toru South Tapanuli Regency.

3. The presence of PT. Martabe Batang Toru has a positive impact on the reduction of poverty in the District of Batang Toru South Tapanuli Regency.

4. The presence of PT. Martabe Batang Toru has a positive impact on the infrastructure of public education in the District of Batang Toru South Tapanuli Regency.
5. The presence of PT. Martabe Batang Toru has a positive impact on the infrastructure of public health in the District of Batang Toru South Tapanuli Regency.

6. The presence of PT. Martabe Batang Toru has a positive impact on the development of technology and information society in the District of Batang Toru South Tapanuli Regency.

\section{Recommendations}

Suggestions from the research that has been done is as follows:

1. PT. Martabe Gold mine is recommended to maintain and improve the program perbedayaan community.

2. Community hope mining Company and government in cooperation, in order to preserve the environment as a result of the activities of mining companies.

3. PT. Martabe Gold mine expected still pay attention to the empowerment of the community in the field of health and education.

4. Need to do further research about the impact of the presence of PT. Martabe Gold mine Batangtoru to the environment posed and after the mine closed.

\section{Acknowledgement: None}

\section{Conflict of Interest: None}

\section{Source of Funding: None}

\section{REFERENCES}

1. A Soedomo Hadi. (2008). Pendidikan (Suatu Pengantar). Surakarta: UNS Press.

2. Azhari, Yusuf. 2014."Analisis Dampak Sosial Dan Kawasan Ekonomi Khusus Penggalian Tambang Emas Di Kec. Batang Toru Kab. Tapanuli Selatan. Skripsi. Departemen Ekonomi Pembangunan Fakultas Ekonomi Dan Bisnis Universitas Sumatera Utara. Medan.

3. Badan Pusat Statistik Kabupaten Tapanuli Selatan.

4. Biara.2016. Kesehatan Masyarakat. Kementerian Kesehatan Indonesia. Jakarta. 
5. Efendi, Ridwan,2014. Analisis Penyerapan Tenaga Kerja Pada Sembilan Sektor Ekonomi Di Sumatera Selatan. Jurnal VOL8 No.1 Januari 2014.

6. Fauzi, A. 2004. Ekonomi Sumberdaya Alam dan Lingkungan Hidup Berdasarkan Prinsip Dasar dan Penerapannya Dalam Pembangunan. Liberty, Bogor.

7. Ghozali, Imam. 2011. Aplikasi Analisis Multivariate dengan Program IBM. SPSS 19 (edisi kelima). Semarang: Universitas Diponegoro

8. Hidayah, Ismatul, 2016. Kajian Dampak Penambangan Emas terhadap Aspek Sosial Ekonomi dan Lingkungan Pertanian di Kabupaten Buru.Banjar Baru : Jurnal.

9. Hidayat, Wahyu. Rustiadi, Ernan. Dan Kartodihardjo, Hariadi. 2014. "Dampak Sektor Pertambangan Terhadap Perekonomian Wilayah Di Kabupaten Luwu Timur". Institut Pertanian Bogor. Jurnal.

10. Hs, Salim. 2005. Hukum Pertambangan di Indonesia. PT. Raja Grafindo Persada, Jakarta.

11. Kehati. 2009. Materi Kursus Inventarisasi Flora dan Fauna Taman Nasional Meru Betiri. Hlm 8, Malang.

12. Kuncoro, Mudrajat, 2003. Metode Riset Untuk Bisnis dan Ekonomi, Edisi 1, Erlangga, Jakarta.

13. Kuncoro, Mudrajad. 2010. Masalah, Kebijakan, dan Politik Ekonomika Pembanguan. Erlangga, Jakarta.

14. Mustifa, Yenli,2012. Aktivitas Tambang Emas Bagi Kesejahteraan Masyarakat di Jorong Subarang Ombak Kanagarian Muaro Kecamatan Sijunjung Kabupaten Sijunjung. Padang: Jurnal.

15. Nachowari dan Usman. 2008. Pengelohan Tekhnik Ekonometrika (Pendekatan Populer and praktik Dilengkapi Teknik Analisis dan Pengelohan Data Dengan Menggunakan Paket Program SPSS). PT. Grafindo Persada. Jakarta.

16. Pasaribu, Arman. 2010. "Analisis Dampak Pertambangan Emas Terhadap Sosial Ekonomi Masyarakat Di Kecamatan Batangtoru Kabupaten Tapanuli Selatan. Universitas Sumatera Utara. Medan.
17. Rahmawaty,2013. Dampak Pertambangan Emas Terhadap Kehidupan Sosial Ekonomi Masyarakat Desa Tulabalo Timur Kecamatan Suwawa Timur, Kabupaten Bone Bolango.Universitas Negeri Gorontalo.

18. Reksoprayitno, Sistem Ekonomi dan Demokrasi Ekonomi. Jakarta. Bina Grafika. 2004

19. Rumidi, Sukandar. 1999. Bahan Galian Industri. Gadjah Mada University Press, Yogyakarta.

20. Simanjuntak P J. 1998. Pengantar Ekonomi Sumberdaya Manusia. Jakarta: FE UI.

21. Sinaga, Murbanto. 2017. Keuangan Daerah. Fakultas Ekonomi dan Binis USU, Medan.

22. Soekartawi, Faktor-Faktor Produksi. Jakarta. Salemba Empat.2002

23. Subri, Mulyadi. 2003. Ekonomi Sumber Daya Manusia dalam Perspektif Pembangunan. PT. Rajagrafindo Persada. Jakarta.

24. Sumarsono, Sonny. 2009. Ekonomi Sumber Daya Manusia Teori dan Kebijakan Publik. Yogyakarta: Graha Ilmu.

25. Sugiyono. 2003. Metode Penelitian Administrasi Dilengkapi Metode R\&D. Alfabeta. Bandung.

26. Suparlan, Parsudi. 2004. Kemiskinan di Perkotaan. Jakarta: Yayasan Obor

27. Suryawati. 2004. Teori Ekonomi Mikro. UPP. AMP YKPN. Yogyakarta: Jarnasy.

28. Sutedi, Adrian. 2012. Hukum Pertambangan. Sinar Grafika, Jakarta.

29. Tantawi, Isma. 2015. Masyarakat Dan Kebudayaan Indonesia. Yayasan Al-Hayat. Medan.

30. Warsita, Bambang. (2008) Teknologi Pembelajaran: Landasan \&Aplikasinya, Jakarta: Rineka.

How to cite this article: Khairul Ali Hutasuhut, HB. Tarmizi SU, Rujiman. Analysis of the impact of the presence of Pt. Martabe Gold Mine Batangtoru on the level of welfare of the Community Batangtoru South Tapanuli Regency. International Journal of Research and Review. 2021; 8(8): 334-341. DOI: https://doi. org/10.52403/ijrr.20210846 